\title{
STEM ATTITUDES OF STUDENTS AS PREDICTOR OF SECONDARY SCHOOL TECHNOLOGY AND DESIGN COURSE ACHIEVEMENT
}

\author{
Kamil Arif Kırkıç \\ Istanbul Sabahattin Zaim University, Turkey \\ E-mail: kamil.kirkic@izu.edu.tr \\ Feriha Uludağ \\ Ministry of National Education, Turkey \\ E-mail: ferihauludag@gmail.com
}

\begin{abstract}
Achievement in a course mostly depends on the students' characteristics and how teachers make their courses effective for their students' learning. Although different characteristics of teachers and students can affect learning outcomes, new approaches like STEM may cause new characteristics which affect students' achievement as STEM attitudes. This study examines the correlation between secondary school students' STEM attitudes and their achievement in the Technology and Design Course ( $T \& D C)$. A correlational survey model was applied in the study. A total of 400 students studying in the seventh and eighth grades constitute the sample of the study. A personal data form and STEM attitude test were utilized to collect data. Pearson Correlation Analysis and Regression Analysis techniques were used in the data analysis process. As a result of the analysis, it was found a positive and significant correlation between students' Technology and Design Course achievement and STEM attitudes. Students' attitudes to STEM predict their achievement in the Technology and Design Course by 5.1\%. Students developing positive STEM attitudes can further enhance achievement in the (T\&DC), which enables students to acquire the necessary design skills to produce technology in the future.
\end{abstract}

Keywords: academic achievement, correlational survey, secondary school, STEM attitude, technology, and design course

\section{Introduction}

The innovative technological advances of the current century make it feel that time is moving faster. Present emerging crises make the concepts of technology, design, and innovation more visible. What is more, these crises highlight those countries with more innovative and technological design industries. Countries' growing, accelerating desire for technological development and breakthrough directly and profoundly affects their education systems. Some countries are updating their education programs to expand the education level in technology, design, engineering, and medicine to close the gap between themselves and developed countries. The Science Technology Engineering Mathematics (STEM) approach, which is expected to attract qualified students to participate in the technology labor force, has been included in the various courses over the last fifteen years. Since 2017, the Turkish Ministry of Education has added the STEM approach to the programs of courses such as mathematics, science, information technology, and technology and design at all school levels to provide more students with more qualified education in science, engineering, mathematics, and technology (MoNE, 2017). 
Kamil Arif KIRKIÇ, Feriha ULUDAĞ. STEM attitudes of students as predictor of secondary school technology and design course achievement

PROBLEMS

OF EDUCATION IN THE $21^{\text {st }}$ CENTURY Vol. 79, No. 4, 2021

586

Education is a process in which students develop ability, attitude, skill, aesthetics, and sensitivity as they take on the national and cultural values and principles of the society in which they live. In the secondary school Technology and Design Course curriculum (T\&DC), the Ministry of National Education (MoNE) emphasizes that the curriculum constitutes an essential element of an education system (MoNE, 2017, p. 4). One of the main goals of the technology and design course curriculum is for each person, through continual education, to transfer their knowledge to practice and create functional works while performing their social tasks as part of lifelong learning. The learning outcomes of technology and design courses are conducive to applying STEM subjects, through which students develop mental processes such as creativity, critical thinking, and problem-solving skills. Individuals with advanced problem-solving skills are open to innovations and changes in science, mathematics, engineering, and technology. They will be able to develop new projects in these areas, therefore benefitting the society in which they live. Individuals who can innovate in STEM have an important role in terms of the country's future and how it responds to international competition. Countries that can produce new technologies will always be one step ahead of global competition. The Technology and Design Course aims to educate individuals to produce such technology. To achieve these goals, the Technology and Design Course should develop positive STEM attitudes in students to train them in problem-solving skills.

\section{Research Problem}

Learning approaches, especially innovative ones like STEM, may alter and enhance traditional education. Although education is a unique process that includes the teaching of knowledge and skills that enrich and facilitate individuals' lives, sometimes education may lose its ability to develop cultural values. Furthermore, it aims to create people who contribute to society while meeting their individual needs. A key element of technology education is to educate individuals with the resources and skills to adapt to rapidly developing technology (Doğan, 2014, p. 6). As in other secondary school education programs, the Technology and Design Course curriculum aims to make students aware of the world's values and those of the country in which they live. A further priority for the program is the education of individuals with the necessary knowledge, skills, and competencies that can be used in daily life in science and technology, areas that are developing rapidly every day (MoNE T\&DC, 2017).

Along with developing technology, the experiences students go through overtime differ and develop very quickly. From this point of view, the gains that students acquire through their education will significantly impact their knowledge and attitudes. The most significant feature of the information age is that it is necessary to activate the cognitive processes, such as analytical thinking style and creativity, necessary for technology and design. It will not be possible to meet people's expectations with monotonous work that only develops manual skills. For this reason, students need to understand the problems arising from the needs of humanity and those that may arise in the future in order to create solutions through design. The main goal of the Technology and Design Curriculum (T\&DC) is to enable students to interpret and use information (MoNE T\&DC, 2017).

Technology is creating new designs through scientific methods and converting knowledge into production, applying knowledge to problems. Technology is also defined as improving the quality of human life by combining science, art, and economy using creativity and intelligence. Technology is a tool for making human life more comfortable, improving the quality of life, and living more economically and efficiently (MoNE T\&DC, 2006).

Using creative thinking, critical thinking, questioning, and reasoning skills, high-level mental processes, design is the material presentation of forms created in the human imagination. Technology and design should be considered as an integral whole since they directly affect each 
other. The relationship between them is not different from the subject and object relationship.

Both concepts are related to all stages in the emergence of a product. Technology and design, therefore, can be used to create essential effects that will ensure the progress and development of society (MoNE T\&DC, 2006). The first aim of the Technology and Design Course is to educate people as individuals to be open to learning throughout their life and willing and able to put what they have learned into practice. The key to social development is educating generations who can apply and use all the technology and design processes for the benefit of their career and the nation. The second goal is to ensure that students who understand the technology and design process can use and interpret information at all levels. These goals are intended to educate individuals to observe their environment analytically, identifying problems, developing creative and original solutions, then deciding and applying the most appropriate of these solutions. While technology and design develop a better quality of life, knowledge of the production process helps to minimize the negative characteristics of technology and design products. Such an approach also aims to teach students to adopt ethical rules related to technology and design. Students who complete the Technology and Design Course are expected to carefully observe their environment, feel a sense of responsibility, develop unique solutions to problems, and work together with confidence to solve the problems they identify (MoNE TDC, 2017). Sağlik (2018), in his study on secondary school students' attitudes toward technology and design courses and their academic achievement, found a moderate, positive, and significant relationship between them.

The primary purpose of this study was to examine the relationship between middle school students' STEM attitudes and technology-design course achievement. Accordingly, this study considers the following question: Do middle school students' STEM attitudes predict their technology design course achievement significantly?

\section{Research Focus}

STEM is an acronym for Science, Technology, Engineering, and Mathematics (Arıkan, 2018, p. 13). The term refers to the intersection of disciplines covered by a holistic approach. This intersection brings the interdisciplinary approach to the forefront and allows students to establish connections between the fields of science, technology, engineering, and mathematics and to use these connections as a flow of knowledge (Eroğlu \& Bektaş, 2016, p. 44).

To overcome current problems in education systems, radical changes have been made in courses to embrace all aspects of the subjects and principles, especially in mathematics and science courses. The STEM approach is the foremost of these changes. To engender positive attitudes to education in the fields of science, technology, engineering, and mathematics, STEM takes a holistic approach to the information and principles of these courses, thereby avoiding piecemeal learning (Çepni, 2017, p. 3). In teaching students to learn information more interactively and systematically as a whole, STEM education allows them to become aware of the problems of the world in which they live and to be able to solve problems they will encounter in the future more efficiently. In parallel with STEM education, from an early age, students could develop different skills in these areas that they can use in real life and turn into production (Aydin et al., 2017, p. 2).

STEM-based teaching aims to increase economic prosperity by increasing the labor force potential in STEM subject areas. As well as achievement or failure of students in terms of their courses, STEM teaching aims to address disparities in the economic race between countries. Countries that create technology innovations and proliferate in inventions are economically aspiring and robust. The industrial period, shaped over the last two centuries, saw the beginning of industrial production, which individuals will realize, and ends in a short period such as the next decade. Today, the skills of "creativity," "critical thinking," "problem-solving," and 
Kamil Arif KIRKIÇ, Feriha ULUDAĞ. STEM attitudes of students as predictor of secondary school technology and design course achievement

PROBLEMS

OF EDUCATION IN THE $21^{\text {st }}$ CENTURY Vol. 79, No. 4, 2021

588

"collaboration" have come to the fore but are obtained by only a tiny section of global society that has gone through a knowledge-based transformation of industry. Adopting this approach is explained by the fact that individuals have the concept of "universal literacy" for technology (Akgündüz et al., 2015). For a country to compete effectively in a globalized world, it is necessary to train its students in STEM education, starting from pre-school, to improve their science, technology, mathematics, and engineering skills (Balat \& Günşen, 2017, p. 339).

There are three main foundations of STEM education: The first is to increase the level of those who would like to improve themselves in the disciplines covered by STEM. The second is to ensure the proliferation of STEM literate individuals, and the third is to increase the use and prevalence of STEM in business areas (Aydin et al., 2017, p. 2).

Attitude is people's response to specific events, objects, or phenomena around them. How they react is gained through learning. To understand someone's attitude, it is necessary to observe their behavior in certain situations. Attitudes could be evaluated individually or can be observed occurring under the influence of a social group. Attitude can be expressed as to how an individual reacts.

Furthermore, an individual's attitude can lead them to adopt a particular form of behavior. Any object, event, individual, or situation can be a leading cause of attitude. Moreover, people's approach to the situation in which they live, such as happiness, unhappiness, good, bad, can also be the subject of attitude (Korkmazyürek \& Haz1r, 2015, p. 63). Many factors affect students' attitudes toward courses, for example, the climate the teacher creates in the classroom, their intimacy with other students, his/her patience, understanding and caring attitudes, and their expectations of the course. Whereas these factors affect their attitudes, their attitudes in turn significantly affect their interest in the course and their achievement (Şimşek \& Demir, 2012, p. 7).

Currently, the need for people who question, think, who have developed their creativity and succeeded in the STEM field is growing every day. Therefore, learning systems need to change so that information is transferred to the sciences. STEM education programs are intended to close this gap and are created by combining all disciplines in a holistic approach (Y1ldirım \& Altun, 2015, p. 30). In Turkey, the Ministry of Education has periodically re-arranged the technology and design curriculum in 2016 and 2017. The technology and design curriculum developed in 2016 focused on the seventh and eighth grades, and in 2017, the technology and design curriculum included the implementation of STEM programs (Ar1kan, 2018, p. 95).

The use of STEM programs at the primary level is mainly aimed at improving scientific knowledge that students can use daily. In this way, it is envisaged that students will improve their program solving skills, thereby increasing their achievement in science, and positively affecting students' attitude to science courses (Gülhan \& Şahin, 2016). The inclusion of STEM education at the secondary level is designed to attract students according to the needs of the information age. Directing students' achievements in science, technology, engineering, and mathematics according to the STEM method is of strategic importance both for their social and personal development (Knezek et al., 2013, cited in Yolagiden \& Bektaş, 2018, p. 3). STEM education ensures that students develop specific characteristics and a positive attitude toward courses. To increase their interest in STEM fields, to popularize engineering, and to achieve achievement by developing positive attitudes toward STEM, it is necessary to introduce students to STEM at an early age. Design-based learning is vital for good engineering education. It is necessary to learn engineering design processes in design-based learning. This educational learning approach allows students to solve real-world problems and is mainly used in science and technology education at the secondary school level. The curriculums in Turkey include science, mathematics, and technology, and design courses (Y1ldirim, 2018, p. 274). Teachers should transfer STEM applications to their students in these courses, conduct experimental, and evidence-based research, and develop their ability to analyze the results of discoveries defined as scientific inventions. 
For this reason, for STEM applications to be helpful in the classroom, it is necessary to have the tool of competence, to give information on how to use this tool, and to analyze the relationship between design processes and daily life. It is also important to increase students' readiness levels in laboratory work practice (Gökbayrak \& Karışan, 2017, p. 64). As it allows individuals to learn and apply information more meaningfully and more in-depth, STEM education and practices are essential for individuals to grow and help them guide their future. Turkey needs to focus on interdisciplinary studies rather than awarding expertise in a single disciplinary field in the coming years. In light of this, educating individuals through STEM education and practices and developing a positive attitude toward STEM disciplines is essential for our future.

\section{Research Aim and Research Questions}

This study aimed to examine the correlation between the STEM attitudes of secondary school students and their achievement levels of the Technology and Design course. Accordingly, the study considers the following questions:

Is there a significant correlation between secondary school students' STEM attitudes and their achievement levels of the Technology and Design Course?

Do secondary school students' STEM attitudes significantly predict their Technology and Design Course achievement?

\section{Research Methodology}

\section{General Background}

In secondary education, students' choices of fields that are the source of STEM fields are closely related to their secondary school achievements. In addition to knowledge and skills, attitudes and values have an important place for individuals to form a personality and gain while passing through the education process. Attitudes are effective in transforming the acquired knowledge into behavior. Students need to develop a positive attitude towards technology and design course to maximize their academic success.

The learning objectives of the technology design course are that STEM subjects are put into practice and students' creativity, critical thinking, problem-solving. It aims to improve high-level mental processes. Individuals with advanced problem-solving skills are open to innovations and changes in the fields of science, mathematics, engineering, and technology and will be able to produce new projects in these areas, and thus will be able to benefit the society they live in. Individuals who can reveal innovations in the STEM field have an important place in the country's future and international competition. Countries that can produce will always be one step ahead in global competition. It aims to train individuals who produce technology design courses. In order to achieve these goals, it is valuable to develop students' STEM attitudes positively and to raise individuals who are successful in STEM fields and have acquired STEM skills in terms of achieving the goals of the technology design course.

This study examines the correlation between secondary school students' STEM attitudes and their achievement in the Technology and Design Course. The correlational survey model was used to answer the research problem. The correlational survey model is a quantitative research method that determines relationships between two or more variables (Karasar, 2002, p. 81). In the correlational survey method, the researcher tries to determine the perceptions of the current situation by reaching the individuals in the study group. The researcher analyzes the relationships between variables from a scientific perspective without interfering with the findings obtained (Gürbüz \& Şahin, 2017, p. 108). The relation between the STEM attitudes 
Kamil Arif KIRKIÇ, Feriha ULUDAĞ. STEM attitudes of students as predictor of secondary school technology and design course achievement

PROBLEMS

OF EDUCATION

IN THE $21^{\text {st }}$ CENTURY Vol. 79, No. 4, 2021

590

of secondary school students and their technology-design course success levels was examined with the relational screening method used in the study.

\section{Participants}

The participants of the research consist of 412 students in seventh and eighth grades studying at the school where the researcher works in the Küçükçekmece district of Istanbul, which falls under the Ministry of Education. Four hundred students studying in the 2017-2018 academic year were included in the study. The study was conducted with a group of students determined by the convenience sampling method. The convenience sampling method is the selection of units with easy access and applicability in cases such as economic limitations, labor, and time insufficiency (Büyüköztürk et al., 2018, p. 82). As the T\&D course teacher, the second author collected the data from the school students where she works as a teacher. The demographic information of the students included in the study is presented in Table 1.

\section{Table 1}

Demographic Information of Students

\begin{tabular}{cccc}
\hline Categories & Groups & $f$ & $\%$ \\
\hline \multirow{2}{*}{ Gender } & Girl & 220 & 55.0 \\
& Boy & 180 & 45.0 \\
\multirow{2}{*}{ Grade Level } & $7^{\text {th }}$ grade & 204 & 51.0 \\
& $8^{\text {th }}$ grade & 196 & 49.0 \\
\hline
\end{tabular}

According to Table 1, 55\% of the research students are girls, and $45 \%$ are boys; $51 \%$ are seventh grade, and 49\% are eighth-grade students. Permission was obtained from the Ministry of National Education Provincial Directorate of National Education to collect the research data. Permission was obtained from the students' school to participate in the study and from the parents of the students. Since the parents of 412 of the students who could participate in the study approved the participation, 412 students participated. However, out of 412 students, only 400 students completed the questionnaires, and 12 students left without completing the questionnairs. For this reason, the analyses were carried out with the data obtained from 400 students.

\section{Instrument and Procedures}

The data collection tools used in this research consisted of two separate forms: "Personal Data Form" and "STEM Attitude Scale".

The researchers created a personal information form to determine students' demographic information. The gender, class levels, and T\&D course points of the students were collected through the personal information form. In addition, the STEM attitude scale, adapted by Aydin et al. (2017), was used to determine students' attitudes to science, technology, mathematics, and engineering. The STEM attitude scale consists of 28 items, and there is no reverse encoded expression in these expressions. Four sub-dimensions were identified in factor analysis through the validity and reliability tests for the scale. These sub-dimensions are as follows: personal and social practices, learning science, engineering and associating with STEM, learning mathematics and associating with STEM, and using and learning technology. The survey is formed as a 
Kamil Arif KIRKIÇ, Feriha ULUDAĞ. STEM attitudes of students as predictor of secondary school technology and design course achievement

PROBLEMS

OF EDUCATION

IN THE $21^{\text {st }}$ CENTURY

Vol. 79, No. 4, 2021

5-point Likert type scale listed from "Strongly Disagree" to "Strongly Agree". The reliability coefficient Cronbach's alpha of the scale obtained in this study was determined as .912, and this value indicates that the scale is reliable. The researchers personally applied the data collection tools used within the scope of the research to seventh and eighth-grade students studying at a Secondary School in the Küçükçekmece district of Istanbul. The researcher explained the questions to be considered on the personal information form and the scales to the students who voluntarily participated in the study. The scale was distributed to 412 students. Since 12 scales were missing or erroneous, they were not included in the assessment.

\section{Data Analysis}

Data obtained from the Personal Information Form was interpreted by creating frequency and percentage tables. The correlation between students' Technology and Design Course achievement and STEM attitudes was tested with the Pearson Moments Correlation Coefficient. Furthermore, simple regression analysis was carried out to determine the achievement of STEM attitudes to the Technology and Design Course. All statistical analyses of the research were conducted using the SPSS 26.0 package program.

\section{Research Results}

As Table 2 demonstrates, skewness and kurtosis values range from -1 to +1 . Finding skewness and kurtosis values between -1 and +1 is one of the indicators of normal data distribution (Büyüköztürk, 2018).

\section{Table 2}

Skewness and Kurtosis Values of STEM Attitude and Achievement Scores

\begin{tabular}{lcc} 
& STEM Attitude & T\&D Course Achievement \\
\hline Skewness & -.586 & -.852 \\
Kurtosis & .169 & -.238 \\
\hline
\end{tabular}

Pearson correlation analysis was performed to determine the existence and the level of the correlation between variables. A simple regression analysis was performed for the predictive state between them.

\section{Table 3}

The Results of Correlational Analysis Between STEM Attitude and Achievement

\begin{tabular}{|c|c|c|c|c|c|}
\hline Variables & $N$ & $M$ & $S D$ & STEM Attitude & $\begin{array}{l}\text { Achievement } \\
\text { Level }\end{array}$ \\
\hline STEM Attitude & 400 & 76.5176 & 19.35575 & - & $.225^{\star *}$ \\
\hline Achievement Level & 400 & 99.0125 & 19.29983 & $.225^{\star *}$ & - \\
\hline
\end{tabular}


Kamil Arif KIRKIÇ, Feriha ULUDAĞ. STEM attitudes of students as predictor of secondary school technology and design course achievement

PROBLEMS

OF EDUCATION

IN THE $21^{\text {st }}$ CENTURY

Vol. 79, No. 4, 2021

According to Table 3, as a result of the Pearson product Moment correlation analysis conducted to determine the relationship between the achievement scores of the Technology and Design Course and the total scores taken from the STEM attitude scale, a statistically significant relationship was found between the scores at level $p<.01(\mathrm{r}=.225 ; p<.01)$. Results of regression analysis conducted to determine the state of regression of students' STEM attitude scale scores in the technology design course are indicated in Table 4.

\section{Table 4}

The Results of Linear Regression Analysis to Check the Prediction Level of STEM Attitude on the Achievement Level

\begin{tabular}{|c|c|c|c|c|c|c|c|c|c|c|}
\hline $\begin{array}{l}\text { Independent } \\
\text { Variable }\end{array}$ & $\begin{array}{l}\text { Dependent } \\
\text { Variable }\end{array}$ & $B$ & $S D$ & $\beta$ & $t$ & $p$ & $R$ & $R^{2}$ & $F$ & $p$ \\
\hline \multirow{3}{*}{ STEM Attitude } & \multirow{3}{*}{$\begin{array}{l}\text { Achievement } \\
\text { Level }\end{array}$} & 54.172 & 1 & \multirow{3}{*}{.225} & 10.964 & .001 & \multirow{3}{*}{.225} & \multirow{3}{*}{.051} & \multirow{3}{*}{21.230} & \multirow{3}{*}{.001} \\
\hline & & & & & & & & & & \\
\hline & & .226 & 398 & & 4.608 & .001 & & & & \\
\hline
\end{tabular}

As Table 4 demonstrates, the STEM attitude scale of students significantly predicts the achievement of the Technology and Design Course $\left(\mathrm{R}=.225, \mathrm{R}^{2}=.051, \mathrm{~F}=21.230, p<.01\right)$. The STEM attitude scale explains $5.1 \%$ of the total variance in students' achievement in the Technology and Design Course. According to the results of the regression analysis, the regression equation is presented below. Achievement in the Technology and Design Course $=$ $54.172+(.226 \times$ STEM Attitude) .

\section{Discussion}

In the European Union countries where the developed countries are the majority, the number of people who prefer STEM professions in their business life is decreasing. Despite the high unemployment rate, the shortage of people trained in STEM professions causes educational institutions to direct more students to STEM professions within students' competencies (Caprile et al., 2015). Students' orientation towards STEM professions at university starts with introducing STEM courses (Science, Mathematics, Information Technologies, Technology, and Design courses) to students at secondary school. If the necessary precautions are not taken, secondary school education of secondary school students is one of the prominent processes in determining the fields to be chosen in high school. In addition to the Mathematics, Information Technologies and Science courses, which are called STEM courses in secondary school, another introductory course is in Technology and Design. Being a pioneer in the production of knowledge and technology determines the future of countries.

Today's students work in the fields that produce technology and enable technological knowledge to become more critical every year. Technology and Design course is also one of the lessons that will affect the training of human resources in technology in Turkey as a developing country. Students who are successful in the Technology and Design course, which is among the STEM courses, are more likely to work in STEM professions in the future. Students' orientation to engineering, which is one of the STEM professions, is related to the attitudes of both teachers and students towards STEM education (Kimmel et al., 2007). As students' success in STEM courses such as the T\&D course increase, their orientation, and interest in STEM professions increases. Therefore, it is vital in terms of creating human resources to produce technology 
(Hirsch et al., 2012). For this reason, improving the STEM attitudes of the students will increase the success of the students in the T\&D course and contribute to the secondary school students choosing a field that goes to STEM professions in high school.

Gülhan and Şahin (2018) studied STEAM (STEM + Art) activities on the academic achievement, STEAM attitude, and scientific creativity of 7th-grade students. It was determined that their academic achievements and general STEAM attitudes improved significantly with a moderate effect. Yıldırım and Selvi (2017) conducted an experimental study on STEM applications and the effects of Mastery Learning. As a result of the research, it was found that STEM applications and Mastery Learning positively affect students' academic achievement and motivation towards science.

One of the prominent factors affecting students' choice of STEM courses and their success in these courses is students' perceptions. Students' thoughts about achieving STEM lessons affect their success and learning levels in STEM lessons (Cedere et al., 2020). The ability to acquire the necessary workforce in the STEM fields is essential for the sharing and expanding development and prosperity. In order to increase the human resources needed in STEM fields in the European Union, the need for individuals who have acquired STEM skills is increasing every day. In order to meet the increasing need, increasing the interest and success of students in STEM fields in secondary school and high school years is suggested as one of the solutions (Caprile et al., 2015).

For Turkey, as a candidate for the European Union and a developing country, STEM education is essential to create a workforce to work in the STEM field. Developing countries' becoming developed countries is closely related to their innovative technology products in different sectors. For these reasons, students should be guided to STEM departments in schools that train the future workforce. It is the secondary school and high school years when the referral will be made. In the Technology Design course, which is one of the STEM courses in secondary school years, determining the effects of students' STEM attitudes on course success will guide practitioners and policymakers.

According to the research results, there was a positive and significant relationship between students' achievement in the Technology and Design Course and their STEM attitudes. In their research on the impact of STEAM (STEM+art) activities on academic achievement, STEAM attitude, and scientific creativity of seventh-grade students, Gülhan and Şahin (2018) determined that students' academic achievement and overall STEAM attitudes improved significantly with a moderate effect.

Katanski (2013) found that American youth's creativity had declined over the past two decades, so technological competitions will help increase interest in STEM subjects and for students to develop positive attitudes toward STEM.

In their research, Kimmel et al. (2007) discuss how most secondary and high school students do not know the engineering field and do not know what an engineer does. They emphasize that, for students to be directed to STEM fields, teachers should be adequately trained in this regard; exceptionally, they should be trained in engineering. They obtained results indicating that children could get an adequate education in STEM and achieve concrete results in cooperation with school, parents, and industry.

Hirsch et al. (2012) engaged secondary school students at the Exxon Mobil Bernard Harris Summer Science Camp at The New Jersey Institute of Technology in the design process, albeit briefly in the summer semester. Students completed the design process, including problem identification, identifying alternative solutions, prototyping, testing, evaluating, and developing positive attitudes to the engineering design process. 
Kamil Arif KIRKIÇ, Feriha ULUDAĞ. STEM attitudes of students as predictor of secondary school technology and design course achievement

PROBLEMS

OF EDUCATION

IN THE $21^{\text {st }}$ CENTURY Vol. 79, No. 4, 2021

594

\section{Conclusions and Implications}

As a result of the research, correlation analysis between the achievement score of the Technology and Design Course and the STEM attitude scale, a positively significant relationship was determined. Regression analysis was carried out to determine whether the STEM attitude scale significantly predicts the achievement of the technology design course. The analysis results suggest that the STEM attitude scale significantly predicts the achievement of the Technology and Design Course. It has been determined that the students' T\&D course success depends on the STEM attitude of the students. Therefore, in order for students to be successful in the T\&D course, teachers are recommended to do the necessary work to develop a positive STEM attitude in students.

In this study, the correlational survey model was used as a research model to examine the relationship between secondary school students' STEM attitudes and their technology design course success. In future studies, Qualitative approaches such as observation, interview, and interview can be used. Thus, in-depth information about the application can be obtained.

In line with the findings of this study, which revealed that students' STEM attitudes are essential for the Technology and Design course, in-service training can be organized for teachers to improve their STEM attitudes in all students. Technology design classes can be developed and improved, especially in public schools, so that STEM education can be realized, and students can design original products.

\section{Acknowledgments}

The authors would like to thank all teachers who participated in the research and Carol Williams and Nurdan Maral for the English language review. This article is prepared from the second author's graduate thesis under the supervision of the first author.

\section{Declaration of Interest}

Authors declare no competing interest.

\section{References}

Akgündüz, D., Ertepınar, H., Ger, A. M., Kaplan Sayı, A. ve Türk, Z. (2015). STEM eğitimi çalıştay raporu: Türkiye STEM eğitimi üzerine kapsamlı bir değerlendirme. [The report of STEM education workshop: An assessment on STEM education in Turkey]. İstanbul Aydın University. https:// www.aydin.edu.tr/tr-tr/akademik/fakulteler/egitim/Documents/STEM\%20E\%C4\%9Fitimi\%20 $\% \mathrm{C} 3 \% 87 \mathrm{al} \% \mathrm{C} 4 \% \mathrm{~B} 1 \% \mathrm{C} 5 \% 9$ Ftay\%20Raporu.pdf

Arıkan, E. (2018). Ortaokulda STEM [STEM in secondary school]. In K. A. Kırkıç, \& E. Aydın (Eds.), Merhaba STEM: Yenilikçi Bir Öğretim Yaklaşımı pp. 95-108. Eğitim Yayınevi.

Aydın, G., Saka, M., \& Guzey, S. (2017). 4-8.sınıf öğrencilerin fen, teknoloji, mühendislik, matematik $(\mathrm{STEM}=\mathrm{FETEMM})$ tutumlarının incelenmesi [Investigation of 4-8th grade students' science, technology, engineering, mathematics (STEM = FETEMM) attitudes]. Mersin Üniversitesi Eğitim Fakültesi Dergisi, 13(2), 737-802. https://doi.org/10.17860/mersinefd.290319

Balat, G., \& Günşen, G. (2017). Okulöncesi dönemde STEM yaklaşımı [STEM approach in preschool period]. Akademik Sosyal Araştırmalar Dergisi, 5(42), 337-348. http://dx.doi.org/10.16992/ASOS.12042

Büyüköztürk, Ş., Kılıç Çakmak, E., Akgün, Ö. E., Karadeniz, Ş., \& Demirel, F. (2018). Bilimsel araştırma yöntemleri [Scientific research methods]. Pegem Akademi.

Caprile, M., Palmen, R., Sanz, P., \& Dente, G. (2015). Encouraging STEM studies Labour DirectorateGeneral for Internal Policies Policy Department A: Economic and scientific policy. https://www. europarl.europa.eu/RegData/etudes/STUD/2015/542199/IPOL_STU(2015)542199_EN.pdf 
Kamil Arif KIRKIÇ, Feriha ULUDAĞ. STEM attitudes of students as predictor of secondary school technology and design course achievement

Cedere, D., Birzina, R., Pigozne, T., \& Vasilevskaya, E. (2020). Perceptions of today's young generation about meaningful learning of STEM. Problems of Education in the 21st Century, 78(6), 920-932. https://doi.org/10.33225/pec/20.78.920

Çepni, S. (2017). Kuramdan uygulamaya STEM+E+A eğitimi [STEM+E+ A education from theory to practice]. Pegem Akademi.

Doğan, S. (2014). Eğitimin işlevleri [Functions of education]. In C. T. Uğurlu (Ed.), Eğitim Bilimine Giriş pp. 1-17. Atalay Matbaası.

Eroğlu, S., \& Bektaş, O. (2016). STEM eğitimi almış fen bilimleri öğretmenlerinin STEM temelli ders etkinlikleri hakkındaki görüşleri [Opinions of STEM-education science teachers about STEM-based course activities]. Ĕgitimde Nitel Araştırmalar Dergisi, 4(3), 43-67. http://dx.doi.org/10.14689/issn.2148-2624.1.4c3s3m

Gökbayrak, S., \& Karışan, D. (2017). STEM etkinliklerinin fen bilgisi öğretmen adaylarının bilimsel süreç becerilerine etkisi [The effect of STEM activities on preservice science teachers' scientific process skills]. Batı Anadolu Eğitim Bilimleri Dergisi. 8(2), 63-84.

Gülhan, F., \& Şahin, F. (2016). Fen, teknoloji, mühendislik, matematik entegrasyonunun (STEM) 5. sınıf öğrencilerinin bu alanlarla ilgili alg1 ve tutumlarına etkisi [The effect of science, technology, engineering, mathematics integration (STEM) on 5th grade students' perceptions and attitudes about these fields]. International Journal of Human Sciences, 13(1), 602-620. http://dx.doi.org/10.14687/ijhs.v13i1.3447

Gülhan, F., \& Şahin, F. (2018). STEAM (STEM+Sanat) etkinliklerinin 7. sınıf öğrencilerinin akademik başarı, STEAM tutum ve bilimsel yaratıcılıklarına etkisi [The effect of STEAM (STEM + Art) activities on 7th grade students' academic achievement, STEAM attitude and scientific creativity]. Journal of Human Sciences, 15(3), 1675-1699. http://dx.doi.org/10.14687/ijhs.v13i1.3447

Gürbüz S., \& Şahin F. (2017). Sosyal bilimlerde araştırma yöntemleri [Scientific research methods in social sciences]. Seçkin Yayıncılık.

Hirsch, L., Berliner-Heyman, S., Carpinelli, J., \& Kimmel, H. (2012). Introducing middle school students to engineering and the engineering design process. 25.846.1-25.846.10. http://dx.doi.org/10.18260/1-2-21603

Karasar, N. (2002). Bilimsel araştırma yöntemi [Scientific research method]. Nobel Yayın.

Katanski, D. (June 3-4, 2013). Bridging the creativity and STEM crisis [Paper presentation]. ASQ Advancing the STEM Agenda Conference. Grand Valley State University- Grand Rapids, Michigan.

Kimmel, H., Carpinelli, J., \& Rockland, R. (September 3-7, 2007). Bringing engineering into K-12 schools: A problem looking for solutions? [Paper presentation]. International Conference on Engineering Education - ICEE 2007 Coimbra, Portugal.

Korkmazyürek, H. ve Hazır, K. (2015). Alg1, tutum ve duygular [Perception, attitude and emotions]. In Ü. Sığrı \& S. Gürbüz (Eds.), Örgütsel davranış (46-92). Beta Basım.

MoNE (2006). Teknoloji ve tasarım dersi (6-7-8.sinıflar) öğretim programı, [Technology and design course $\left(6^{\text {th }}, 7\right.$ th and 8 th grades $)$ curriculum $]$. MEB Yayınevi.

MoNE (2017). Teknoloji ve tasarım dersi (7.ve 8.sinıflar) ögretim programı, [Technology and design course (7th and 8th grades) curriculum]. MEB Yayınevi.

Sağlık, M. A. (2018). Ortaokul öğrencilerinin teknoloji ve tasarım dersine yönelik tutumları ile akademik başarılarının incelenmesi [Investigation of secondary school students' attitudes towards technology and design course and their academic achievement]. Journal of Social and Humanities Sciences Research, 5(30), 4411-4427. http://dx.doi.org/10.26450/jshsr.894

Şimşek, H., \& Demir, A. (2012). İlköğretim II. kademe öğrencilerinin sosyal bilgiler dersine yönelik tutumları ve ögrencilerin tutumları ile akademik başarıları arasındaki ilişki [Primary Education II. Level students 'attitudes towards social studies course and the relationship between students' attitudes and academic achievement]. İnönü Üniversitesi Eğitim Fakültesi Dergisi, 13(2), 1-19.

Yıldırım, B. (2018). Sınıf öğretmeni adaylarının tasarım temelli öğrenmeye yönelik görüşleri [Classroom Teacher Candidates' Views on Design Based Learning]. Mediterranean Journal of Educational Research, 12(24), 272-293. http://dx.doi.org/10.29329/mjer.2018.147.15

Yıldırım, B., \& Altun, Y. (2015). STEM eğitim ve mühendislik uygulamalarının fen bilgisi laboratuar dersindeki etkilerinin incelenmesi [The effects of STEM Education and engineering applications in the science laboratory course]. El-Cezerî Fen ve Mühendislik Dergisi, 2(2), 28-40.
PROBLEMS

OF EDUCATION

IN THE $21^{\text {st }}$ CENTURY

Vol. 79, No. 4, 2021 
Kamil Arif KIRKIÇ, Feriha ULUDAĞ. STEM attitudes of students as predictor of secondary school technology and design course achievement

PROBLEMS

OF EDUCATION

IN THE $21^{\text {st }}$ CENTURY

Vol. 79 , No. 4, 2021

596

Yıldırım, B., \& Selvi, M. (2017). STEM uygulamaları ve tam öğrenmenin etkileri üzerine deneysel bir çalışma [An experimental study on STEM applications and the effects of mastery learning]. Eğitimde Kuram ve Uygulama, 13(2), 183-210.

Yolagiden, C., \& Bektaş, O. (2018). Ortaokul öğrencilerinin fen, teknoloji, mühendislik ve matematik (STEM) tutumları ile STEM mesleklerine yönelik ilgileri arasındaki ilişki [The relationship between secondary school students' science, technology, engineering and mathematics (STEM) attitudes and their interest towards STEM professions]. Akademik Sosyal Araştırmalar Dergisi, 6(77), 500-521. http://dx.doi.org/10.16992/ASOS.13922

Received: March 23, 2021

Accepted: July 09, 2021

Cite as: Kırkıç, K. A., \& Uludağ, F. (2021). STEM attitudes of students as predictor of secondary school technology and design course achievement. Problems of Education in the $21^{\text {st }}$ Century, 79(4), 585-596. https://doi.org/10.33225/pec/21.79.585

\section{Kamil Arif Kırkıç}

(Corresponding author)
PhD, Assistant Professor, Istanbul Sabahattin Zaim University, Halkalı Cad. No: 281 Halkalı Küçükçekmece, Istanbul, Turkey.

E-mail: kamil.kirkic@izu.edu.tr

ORCID: https://orcid.org/0000-0002-8902-437X

Ministry of National Education, Turkey

E-mail: ferihauludag@gmail.com 